\title{
Intervention on The Role of Procurement Service Unit
}

\author{
Hario Dharma ${ }^{a} *$ \\ ${ }^{a}$ Pemerintah Provinsi Jawa Timur
}

INFORMASI ARTIKEL

\section{Article history:}

Data submission : 05 October 2017

$1^{\text {st }}$ revision: 10 November 2017

Accepted: 16 December 2018

Available online: 30 December 2018

Keywords: Procurement Service Unit, eprocurement, intervention

\begin{abstract}
The purpose of this paper is to know more about the role of Procurement Service Unit in public procurement process in Indonesia and how government possibly intervene their decision because of their position as part of the government even though they should play a neutral position in the process. The establishment of this Procurement Services Unit actually is intended to be a mediator connecting users (government) with agents (providers/ suppliers). This research applied a qualitative content analysis approach. Data were collected through observation of secondary documents in January 2018. The research was conducted in Regional Office of Environmental Health and Disease Control Surabaya. The results show that the role of Procurement Service Unit needed to be expanded, not only just choosing the bidding winner but also take more control on procurement process. However, this unit already played the neutral position even though they were attached to the institution within their interventions, because of the introduction of e-procurement in Indonesia. But still, it can be argued because it is still need some approval from the actors itself, including the Procurement Service Unit, User, and the providers.
\end{abstract}

2018 FIA UB. All rights reserved.

\section{Introduction}

Procurement Service Unit is a variable key for Public Procurement Process to determining development outcomes and, when carried out in an efficient and transparent manner especially in Indonesia, it can play a strategic role in delivering more effective public services. Public Procurement itself can act as a powerful tool for development with profoundly positive repercussions for both good governance and more rapid and inclusive growth (World Bank Group, 2016). Countries capable of controlling corruption in the public procurement sector are able to use their human and financial resources more efficiently, attract more foreign and domestic investment, and on average grow more rapidly. This expectation also occurs in Indonesia, and the Indonesian Government has attempted to respond to this call through numerous activities, such as strengthening the capacity of officials who work on

\footnotetext{
* Corresponding author. e-mail: haryodharma@yahoo.com
}

public procurement, and establishing an electronic procurement (e-procurement) system (Wibowo, 2017).

E-procurement has started to be practiced in Indonesia, especially in the public sector since 2010, after Presidential Regulation No. 54 of 2010 introduced e-procurement of certain goods and services as a mandatory procurement method, which by 2010 was voluntary. This type of electronic transaction is adopted from e-business and e-commerce due to the rapid changes in the use of information, communication, and technology (ICT) (Walker \& Harland, 2008). Just like ebusiness and e-commerce, e-procurement also has value of transparency, efficiency and effectiveness with aims to improve transparency and accountability; improve market access and fair competition; improve procurement process efficiency; supporting monitoring and auditing processes; and meet the need for real-time access to information (as stated in Presidential Regulation No. 54 of 2010). In practice, e-procurement implementation still has some constraints, such as the 
lack of human resources with good ICT skills, limited internet connections, and the unpreparedness of construction companies to face the implications of digital change (Walker and Harland, 2008).

Therefore, the establishment of Procurement Services Unit already introduced as the executor of the procurement process of goods and services in accordance with the provisions of Presidential Regulation No. 54 of 2010 which has undergone a fourth change in Presidential Regulation No. 4 of 2015 on Procurement of Government Goods/Services. Procurement Services Unit itself was established with the aim that the procurement process of government goods/services can be implemented effectively, efficiently, transparently, and accountable. It is expected that with the establishment of Procurement Services Unit can eliminate the problems that often arise in public procurement, namely the high number of leakage of development funds sourced from the procurement activities of government goods and services.

Through the Procurement Services Unit, all procurement activities are conducted centrally by promoting the optimal utilization of information technology. The officers are the people of choice, at least those assigned to manage the Procurement Services Unit must be able to learn quickly, have a good level of hospitality and do not stutter the development of technology, especially in operationalize the computer. Many Procurement Services Units are managed independently although there are still many attached to the district secretariat or Technical Implementation Unit. At the beginning of its establishment, this unit get a lot of negative sentiment. Those skeptical of the Procurement Services Unit are usually those who are reluctant to learn new ways and new work models. Not even a few providers/ suppliers are underestimating this unit, especially those whose offer is not eligible to win. Indeed, the system built by the government in the Procurement Services Unit is considered a very good and transparent step. Where contact between parties is made as small as possible even nil. Anyone who becomes the winning bidder is a bidder who has all the administrative completeness and best offer value (not just the bidder with the lowest score only). By maximizing information technology, the gap to commit a crime is close to zero. Even if there are negative actions that could damage the reputation of the government, they can quickly detect and take immediate action.

Research in Public Procurement have been widely documented implementation and impact of public procurement alongside with e-procurement system in the governmental institution. Although those research provide important findings, must of them rarely focus on intervention on the role of Procurement Services Unit. In this paper, I utilized those gap by exploring more on the intervention on the role of Procurement Services Unit.

In sum, this paper addressed two questions: (a) What is the actual main role of the Procurement Service Unit?; and (b) How the intervention from institution could be minimize in the procurement process?.

\section{Theory}

\subsection{Principal Agent Theory as a Foundation of Public Procurement}

Principal agent (PA) theory often promoted as one of the most useful tools for investigating and understanding problems relating to corruption - when people definitely do the wrong thing when they are not being watched (Widmalm, 2016). PA theory defines the issues that arise when the parties to a contract have divergent goals and there is information asymmetry between them (Ferris \& Graddy, 1998). This model forms the basis for a formal model of contractual relationships to make it easier to understand how governments manage to produce publicly available services.

In corruption studies we can see that it has been emphasized since the late 1980s (Jensen \& Meckling, 1976). The general idea comes from economists who regard actors as customers or clients. In today's PA theory we see that the principal is an actor who may represent a particular interest - e.g. public interest. Agent is another actor who should take some action for the principal - for example, to provide some public service. However, sometimes the agent is trying to pursue his own interests, not the interests of the principal. This is also known as the "agency" problem. According to PA theory, agency problems arise when there is a kind of "information asymmetry" between principals and actors. In other words, the principal does not know what the agent is doing.

Public procurement is a precise presentation of how a PA theory being implemented in real circumstances. The principal (the contracting government) and the agent (the private contractor, state government, or public bureau) may have different goals, and the agent can have the advantage of information that can be used for its own strategic advantage. Thus, such arrangements, which are often pursued for efficiency gains (reduced production costs) may require significant transaction costs to ensure public accountability.

\subsection{E-Procurement Implementation}

Procurement of goods and services have developed into electronic-based procurement. E-procurement is a technology designed to facilitate the procurement of goods and services over the internet. All procurement activities are prepared electronically, and the function of procurement is supported by electronic communications (Sadono, Wijaya, Wanto, \& Fujimoto, 2017). From the various studies done based on the experience of the countries around the world, the implementation of eprocurement is to prevent or to reduce the level of corruption (Neupane, Soar, Vaidya, \& Yong, 2012). EProcurement can improve the efficiency over traditional procurement methods (Hanna, Bishop, Nadel, Scheffler, $\&$ Durlacher, 2011). The process of goods and services procurement electronically has obviously omitted the use of paper for the providers or the budget users. The providers just upload all documents by the existing web site without coming to the office. e-Procurement can also reduce the less necessary projects. With eprocurement, only the projects needed by the people 
need be sold at auction. However, this assumption is only valid in the economically advanced countries. In developing countries, many projects are proposed by politicians for their personal interests (Gordon Murray, 2009).

E-procurement ensures secure online bid submission and access to bid opening event to the procuring entities, as well as bidders from any place on 24/7 bases. Important benefits of E-procurement compared to offline tendering are (Panduranga, 2016): (1) Wide publicity: The tender document gets wide publicity as it is mandatory for government entities to publish tenders on website/ portal. The vendors can easily find the tenders in which they can participate; (2) Easy to participate: For the vendors it is quite easy to participate in the public procurement tenders floated on website/ portal. All the required documents are to be scanned and uploaded. The system generates an acknowledgment for submission of the online tender. There is no need to submit documents by post, there are no worries of postal delays. It is less expensive and less tedious work to submit the bids online; (3) Large number of bidders: The procuring entity can expect more number of bids for online tenders, as it is widely publicized and it is easy for the vendors to submit bids. However, in the initial stages there are teething problems of resistance to change and adoptability to the online tendering; (4) Transparency: Transparency is the need of the hour in public procurement. One bidder can see the bids submitted by the other bidders. Hence, the procuring entity cannot discriminate any bidder. All the bids are evaluated as per the tender norms; and (5) Check on corruption: There is a possibility of corruption in offline tenders. But this problem does not persist under eprocurement.

\subsection{Procurement Service Unit}

Based on Indonesia's Presidential Regulation No.4/2015, the roles and responsibilities of procurement organizations can be explained as follows (Sadono et al., 2017):

a) National Public Procurement Agency (LKPP) is a non-departmental government agency, the main duties of which are preparation and formulation of policies and strategies, as well as the determination of, the standard procedures for public procurement; it is also responsible for developing information systems and monitoring e-procurement implementation;

b) Procurement Service Unit (ULP) is a government organization that has the function of carrying out eprocurement; and

c) Electronic Procurement Services (LPSE) is a unit formed across ministries, agencies, institutions, and local governments to manage e-procurement services and facilitate the Procurement Service Unit (ULP) in carrying out e-procurement.

From the definition, Procurement Service Unit is a permanent unit containing numerous procurement officials at each public body (Wibowo, 2017). Procurement Service Unit officers are the people of choice, at least those assigned to manage the
Procurement Service Unit must be able to learn quickly, have a good level of hospitality and do not stutter the development of technology, especially in operationalize the computer. Procurement Service Unit officers has the power to prepare the procurement document. Also, it has powers to announce tender opportunities, to evaluate bidding proposals, and to answer bid protests (a review mechanism) at first instance (Wibowo, 2017). Many Procurement Service Units are managed independently although there are still many attached to the district secretariat or Technical Implementation Unit, as written in Presidential Regulation no. 4/2015, the Procurement Service Unit, is a unit of ministry/ institution/ local government/ institutional organization which functions to implement procurement of goods/ services that are permanent, able to stand alone or attached to an existing unit.

\subsection{Political Intervention}

In general, intervention is an act of interference by a country to another country, whether in the economic, social, cultural, political and other social fields. For example, the existence of a State is threatened by the problems arising in the State, while the solution of the problem is considered unacceptable and different handling by the other so that there are differences in attitude and views. As a result, it will be a subjective solution (according to the truth itself) that is by mixing hand or intervention to be acknowledged of his will and simultaneously inculcate his influence from the intervening State (Parry \& Grant, 1986).

According to J.G. Starke, there are three typologies in looking at an intervention of the State against another State, that is (Starke, 1978)

a) Internal Intervention: intervention by a State in the internal affairs of another Country;

b) External Intervention: an intervention by a State in the foreign affairs of a State with another State. Example: Italian involvement in supporting Germany in the Second World War; and

c) Punitive Intervention: the intervention of a State against another State in return for the harm suffered by that State.

An allowable act of intervention can be distinguished into two, namely interventions which are based on a right and other action which, although not by a right, is permitted by international law. As said by L. Oppenheim (1952):

That intervention, as a rule, forbidden by international law, which protect the international personality of the state, there is no doubt, on the other hand, there is just a little doubt, that this rule has exception, for there are intervention which take place by right, and there are other which, although they do not take place by right, are nevertheless permitted by international law.

Other scholars argue that intervention is not the right of a State, but rather sanctions of rights held by States (Brierly, 1963). So it can be said that the intervention is a law enforcement which in certain cases the implementation is given to certain countries. Regardless of whether an intervention constitutes a right or 
constitutes a delegation of authority from international law, a State may intervene for several reasons. J.G Starke considers that the State's intervention on the sovereignty of another State is not necessarily an unlawful act. He argues that there are certain cases where intervention action may be justified under international law. The intervention action are (Starke, 1978):

a) The collective intervention set out in the Charter of the United Nations;

b) To protect the rights and interests, and the safety of its citizens in other States;

c) Self-defense. If intervention is needed immediately after an armed attack occurs. Self-defense conditions are: direct (instant), supportive situation (overwhelming situation), no other way (leaving no means), no time to weigh (no moment of deliberation). These conditions were adopted from the case of the Caroline ship;

d) Related to the Protectorate State over its dominion; and

e) If the State to be intervened deemed to have committed grave breaches of international law.

In the bureaucratic and political activities, Azhari (2011) in his article said that the political intervention is an attempt made by political officials in influencing the process of recruitment and promotion of bureaucrats in bureaucratic posts. Furthermore, he also explained that political intervention on bureaucracy is an action performed by political officials who are not in line with the spirit of bureaucratic neutrality and the rule of law applicable in public bureaucracy management. Such interventions are often made solely for the benefit of party and individual political officials (Azhari, 2011). The impact of these political interventions makes merit systems extremely difficult to implement when decisions that should be taken by objective considerations often turn to accommodate certain interests (Martini, 2010).

\section{Research Method}

This research applied a qualitative content analysis approach (Krippendorff, 2004). In this study I focused on the role of the Procurement Service Unit in Regional Office of Environmental Health and Disease Control Surabaya under the authority of Ministry of Health in the public procurement process and the professionalism of its members both as government employees and as a unit mentioned that must have a neutral position. This study was unique due to as one of the Technical Implementing Units of the ministries in the region, the existing form of Procurement Service Unit differs from that used in local and provincial governments. If the average Procurement Service Unit in the local government stands as an independent unit, it is different from what happened in Regional Office of Environmental Health and Disease Control Surabaya, where the Procurement Service Unit is part of the institution.

Data were collected through observation of secondary documents in January 2018 including: Indonesia's Presidential Regulation Number 4/2015,
Regulation of The Head of Government Procurement Policy Agency Number 5/2015, Regulation of the Minister of Health Number 1893/2011, General Procurement Plan 2017 and Procurement Report 2017 of Regional Office of Environmental Health and Disease Control Surabaya.

The data were analyzed by content analysis approach to know a particular role vis-a-vis their objects of inquiry to make that role becomes clear (Krippendorff, 2004). Krippendorff offered a simple and general conceptual framework for content analysis which is depicted in figure 1, employing only a few conceptual components: A body of text; a research question; a context of the analyst's choice; an analytical construct,

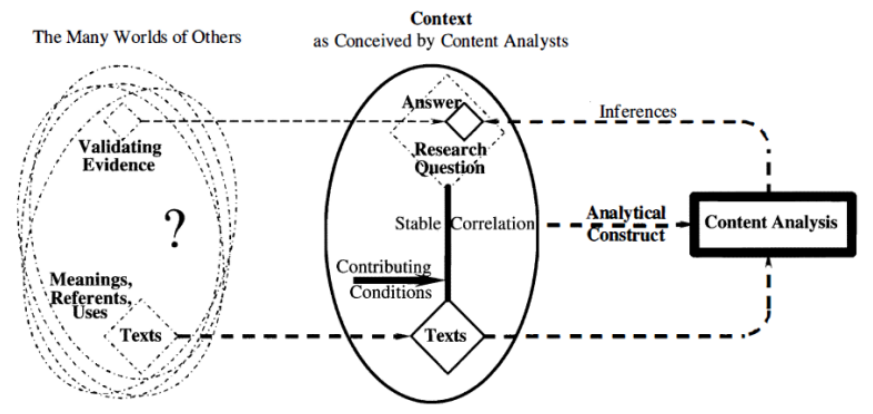

inferences; and validating evidence.

Figure 1. A Framework for Content Analysis Source: Krippendorff, 2004

\section{Results and Discussion}

The findings highlight that the role of Procurement Service Unit represents mainly in Regulation of the Minister of Health Number 462/2010 and 1893/2011. Based on Regulation of the Head of Government Procurement Policy Agency Number 5/2012, 2/2015 and 5/2015 on Procurement Service Unit, the establishment of a procurement service unit aims to: ensure the implementation of more integrated procurement in accordance with Procurement Values; and improve effectiveness and efficiency in the execution of duties and functions of Ministries/Institutions/Regions.

Those aims became a basis for establishment of Procurement Service Unit in Regional Office of Environmental Health and Disease Control Surabaya. This unit was established since the enactment of Presidential Regulation number 54 of 2010 on Procurement of Government Goods/ Services. Mandate of the establishment of this unit ordered directly from the Health Ministry as the headquarters of the Regional Office of Environmental Health and Disease Control Surabaya. The mandatory is written in the Regulation of the Minister of Health Number 1893/2011 on Procurement Service Unit within the Ministry of Health. According to the regulation, Regional Office of Environmental Health and Disease Control Surabaya categorized as Procurement Service Unit at Technical Implementation Unit that have in charge of organizing and coordinating all procurement of goods/ services conducted at the level of Technical Implementation Unit. This unit shall be assigned by the respective 
Director-General which in this case is the authority of the Director-General for the Prevention and Control of Disease.

The organization of Procurement Service Unit consisted of the Head, Administration/ Secretariat, and Working Groups with qualifications as shown in table 1. There are several things to consider if we look at the qualifications of the organizational structure of this unit. To be appointed as a Head of Procurement Service Unit, he/ she must have specific qualification which are he/ she must have minimum undergraduate education, managerial qualification, and experience in the procurement process. It is slightly different for Working Group members that must have a certificate of governmental procurement and can be established as required in the form of procurement working groups for goods, construction works, consulting services, and other services. Also for administration/ secretariat position can be hold by administrative/ financial staff, planning staff, and legal staff.

Other than Procurement Service Unit, there is one position that have the same job, Procurement Officer. Even though both do the procurement, but in terms of authority there are differences. The procurements that can be handled by Procurement Service Unit are (1) procurement of goods/ construction work/ other services with value up to $\mathrm{Rp} 100.000 .000 .000,00$ (one hundred billion rupiah); and (2) procurement of consultancy services with value above Rp 10.000.000.000,00 (ten billion rupiah). According to Indonesia's Presidential Regulation Number 4/2015, procurement officer is a person who appointed to do e-purchasing and direct procurement for procurement of goods/construction work/other services with value up to Rp 200.000.000,00 (two hundred million rupiah) and procurement of consultancy services with value up to Rp 50.000.000,00 (fifty million rupiah).

Table 1. Procurement Service Unit Qualifications

\begin{tabular}{|c|c|c|}
\hline $\begin{array}{c}\text { Head of } \\
\text { Procurement Service } \\
\text { Unit }\end{array}$ & $\begin{array}{c}\text { Administration/ } \\
\text { Secretariat }\end{array}$ & Working Groups \\
\hline $\begin{array}{l}\text { a. Status as a civil } \\
\text { servant } \\
\text { b. Minimum } \\
\text { undergraduate } \\
\text { education } \\
\text { c. has technical and } \\
\text { managerial } \\
\text { qualifications } \\
\text { d. have the ability to } \\
\text { make decisions } \\
\text { e. have moral } \\
\text { integrity, honesty, } \\
\text { discipline and } \\
\text { responsibility in } \\
\text { carrying out the } \\
\text { task } \\
\text { f. has experience as a } \\
\text { procurement } \\
\text { officer/ } \\
\text { procurement } \\
\text { committee } \\
\text { g. understand all types } \\
\text { of work that }\end{array}$ & $\begin{array}{l}\text { a. Status as a civil } \\
\text { servant } \\
\text { b. have moral } \\
\text { integrity, } \\
\text { honesty, } \\
\text { discipline and } \\
\text { responsibility in } \\
\text { carrying out the } \\
\text { task } \\
\text { c. understand all } \\
\text { types of work } \\
\text { that become the } \\
\text { tasks of the } \\
\text { Procurement } \\
\text { Working Group } \\
\text { d. other terms } \\
\text { specified in the } \\
\text { employment } \\
\text { rules for } \\
\text { equivalent } \\
\text { positions }\end{array}$ & $\begin{array}{l}\text { a. } \begin{array}{l}\text { Status as a } \\
\text { civil servant }\end{array} \\
\text { b. Have a } \\
\text { certificate of } \\
\text { governmental } \\
\text { procurement } \\
\text { of goods/ } \\
\text { services } \\
\text { c. have moral } \\
\text { integrity, } \\
\text { honesty, } \\
\text { discipline and } \\
\text { responsibility } \\
\text { in carrying } \\
\text { out the task } \\
\text { d. understand } \\
\text { the overall } \\
\text { procurement } \\
\text { job to be } \\
\text { implemented } \\
\text { e. understand all } \\
\text { types of work } \\
\text { that become }\end{array}$ \\
\hline
\end{tabular}

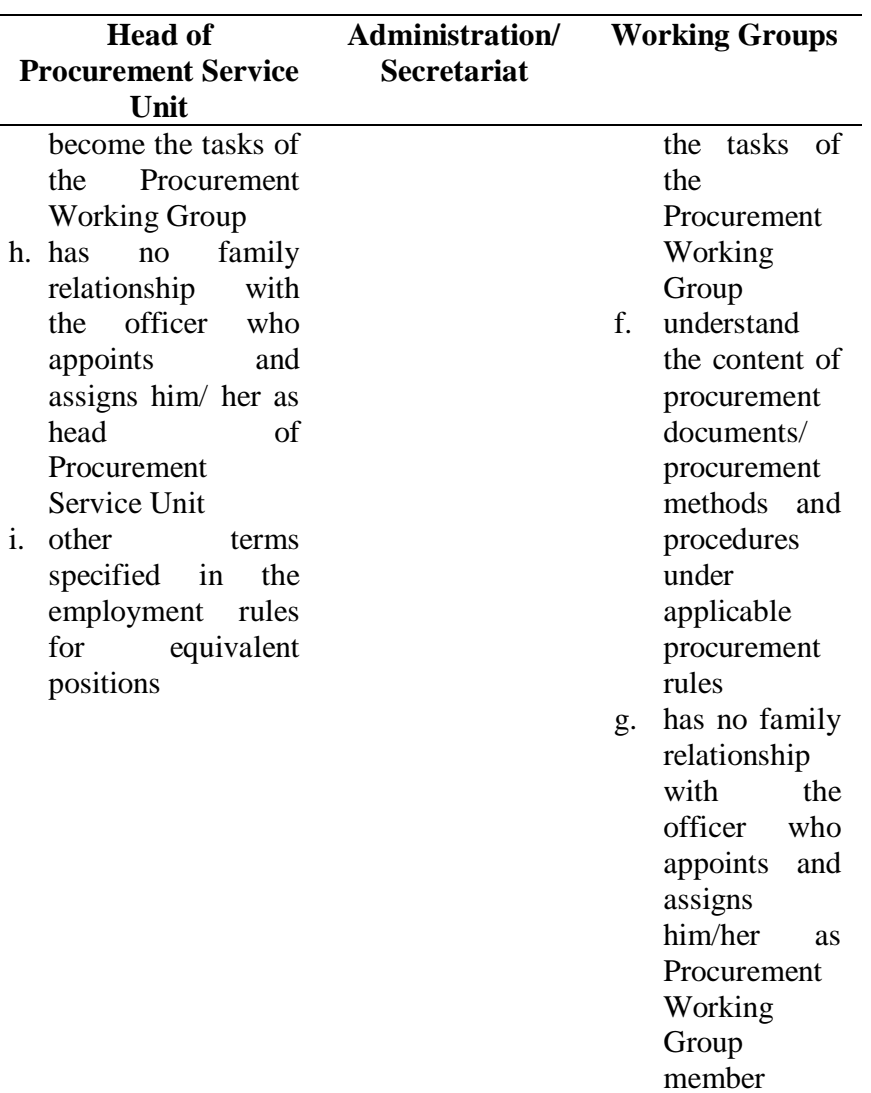

Source: Analytical result, 2017

In its daily duties, the Procurement Service Unit has the following tasks:

a) Preparing the plan for the selection of goods/ service providers;

b) Perform analysis and establish procurement documents;

c) Announce the procurement on the website of the Ministry of Health and the official announcement board for the community and to be announced in the National Procurement Portal;

d) Assess the qualification of the goods/ service provider through prequalification or postqualification;

e) Conduct administrative, technical and price evaluations of incoming bids;

f) Answer the rebuttal from the provider of goods/ services;

g) Submit copies of goods/ services provider selection documents to the Committing Officer;

h) Archiving original goods/ services provider documents;

i) Make a report on the procurement process and results to the Secretary General/ Director General/ Head of the Agency and provide accountability for the procurement of goods/ to Budget User/ Proxy User of Budget;

j) Consult the Budget User/ Proxy User/ Committing Officer in order to solve the problems faced in the procurement process;

k) Proposing changes in the Acquisition Price and technical specifications of the work to the Committing Officer; 
1) Implementing the dissemination of government procurement strategies, policies, standards, systems and procedures for procurement;

m) Carry out human resources development in the field of procurement; and

n) Implement the procurement by utilizing information technology through e-procurement

In addition to the main tasks, the Procurement Service Unit also have the authorities, namely:

a) Establish procurement documents;

b) Determine the nominal amount of the bid security;

c) Stipulates the providers of goods/ construction works/ other services with the highest value of $\mathrm{Rp}$ $100,000,000,000.00$ (one hundred billion rupiahs) and the highest valued consultancy services of $\mathrm{Rp}$ 10,000,000,000.00 (ten billion rupiahs);

d) Proposes the award of the winner to the Minister of Health for the providers of construction goods/ other works worth more than Rp 100,000,000,000.00 (one hundred billion rupiahs) and consultancy services valued above $\operatorname{Rp} 10,000,000,000.00$ (ten billion rupiahs); and

e) Propose providers of goods/ services performing acts and acts such as fraud/ forgery and other offenses, to the Budget User/ Proxy User of Budgeting to be subject to sanctions.

From the experience of Regional Office of Environmental Health and Disease Control Surabaya in 2017, the Procurement Service Unit is still can be neutral when they do the procurement works. It could be described as following:

Beginning with the determination of the work plan of the Work Unit in early 2017 with a total budget allocation of about 28 billion rupiahs. About $37.15 \%$ of the total budget is the work in the field of procurement. With the observation of the 2017 Procurement General Plan, it is seen that about 7 billion rupiahs is allocated for the auction package which is the authority of the Procurement Service Unit and the remainder is the authority of the procurement official. Due to the focus of this article only on the Procurement Service Unit, the work done by procurement officials is not included in this article. This procurement project focuses primarily on build laboratory buildings for Disease Prevention and Control Laboratory and its facilities and infrastructure which are planned to be centers for studies and research of diseases mainly from animals and viruses.

This is evident in the Goods and Services Procurement report as shown in Table 4.2. In a report submitted on 31 December 2017, it appears that about 6 billion rupiahs was allocated to the building in Nongkojajar, Pasuruan. Every auction packages like shown in Table 4.2 could be easily found in Indonesia's Ministry of Health e-procurement system (http://www.lpse.depkes.go.id/eproc4), it was indicated that the Procurement Service Unit in Regional Office of Environmental Health and Disease Control Surabaya using appropriate procedures and steps. I positively sure about this thing because by using the website, everybody could control every action taken by the unit or the providers for sure. The building itself has been officially opened by the Director General of Disease
Prevention and Control, Ministry of Health on November 25th 2017.

Table 2. Goods and Services Procurement Report of Regional Office of Environmental Health and Disease Control Surabaya

\begin{tabular}{|c|c|c|c|c|c|}
\hline \multicolumn{6}{|c|}{2017} \\
\hline No & Description & $\begin{array}{c}\text { Budget } \\
\text { (Rupiah) }\end{array}$ & $\begin{array}{l}\text { Contract } \\
\text { Value } \\
\text { (Rupiah) }\end{array}$ & $\begin{array}{c}\text { Contract } \\
\text { period }\end{array}$ & Progress \\
\hline 1 & $\begin{array}{l}\text { Construction } \\
\text { of Supporting } \\
\text { Building of } \\
\text { P2P Regional } \\
\text { Surveillance } \\
\text { Laboratory } \\
\text { BSL II } \\
\text { Standard }\end{array}$ & $1,465,215,000$ & $1,360,438,200$ & $\begin{array}{l}\text { January } \\
19^{\text {th }}-\text { May } \\
19^{\text {th }} 2017 \\
\text { (4 } \\
\text { months) }\end{array}$ & Done \\
\hline 2 & $\begin{array}{l}\text { Construction } \\
\text { of Utilities of } \\
\text { P2P Regional } \\
\text { Surveillance } \\
\text { Laboratory } \\
\text { BSL II } \\
\text { Standard } \\
\text { (Road, } \\
\text { Environment, } \\
\text { Fence, } \\
\text { Drainage) }\end{array}$ & $1,829,563,000$ & $1,728,137,400$ & $\begin{array}{l}\text { January } \\
19^{\text {th }} \text {-May } \\
19^{\text {th }} 2017 \\
\text { (4 } \\
\text { months) }\end{array}$ & Done \\
\hline 3 & $\begin{array}{l}\text { Construction } \\
\text { of Generator } \\
\text { Set House and } \\
\text { WWTP of } \\
\text { P2P Regional } \\
\text { Surveillance } \\
\text { Laboratory } \\
\text { BSL II } \\
\text { Standard }\end{array}$ & $1,740,222,000$ & $1,631,162,000$ & $\begin{array}{l}\text { January } \\
19^{\text {th }}-\text { May } \\
19^{\text {th }} 2017 \\
\text { (4 } \\
\text { months) }\end{array}$ & Done \\
\hline 4 & $\begin{array}{l}\text { Purchasing of } \\
\text { Laboratory } \\
\text { Equipment } \\
\text { and tools of } \\
\text { P2P Regional } \\
\text { Surveillance } \\
\text { Laboratory } \\
\text { BSL II } \\
\text { Standard }\end{array}$ & $1,015,000,000$ & $969,831,500$ & $\begin{array}{l}\text { September } \\
22^{\text {nd_ }} \\
\text { December } \\
20^{\text {th }} 2017 \\
(3 \\
\text { months })\end{array}$ & Done \\
\hline 5 & $\begin{array}{l}\text { Shopping } \\
\text { Services for } \\
\text { Cleaning } \\
\text { Service }\end{array}$ & $450,000,000$ & $422,560,000$ & $\begin{array}{l}\text { January } \\
23^{\text {rd }}- \\
\text { December } \\
31^{\text {st }} 2017 \\
\text { (11 } \\
\text { months) }\end{array}$ & Done \\
\hline 6 & $\begin{array}{l}\text { Purchasing of } \\
\text { Material and } \\
\text { Reagent on } \\
\text { Bio Molecular } \\
\text { Surveillance } \\
\text { Dengue Virus }\end{array}$ & $400,000,000$ & $378,400,000$ & $\begin{array}{l}\text { January } \\
31^{\text {st }}- \\
\text { March } \\
31^{\text {st }} 2017 \\
(2 \\
\text { months })\end{array}$ & Done \\
\hline
\end{tabular}

Source: Analytical result, 2017

However, there are things to note in this public procurement process. In addition to being part of the Procurement Service Unit at the Regional Office of Environmental Health and Disease Control Surabaya, its members are also civil servants who have the main duties and main functions of the agency, both as administrative executives and as technical executors. Conflicts of interest may occur here when their superiors propose procurement of goods/ services beyond the prescribed budget ceilings assuming that the goods/ services demanded are urgently needed and must be met promptly to support the ongoing programs/ activities. Therefore, there is a need for mechanisms or procedures to be mutually agreed upon before the procurement process runs in order to minimize this conflict: 
a) Proper and careful procurement planning before the current budget year. Although in its implementation the budget may change according to the development of the State Revenue and Expenditure Budget (APBN), with proper planning, procurement of essential goods/ services can still be accomplished without the need for revisions;

b) Procurement planning should involve all implementing members of the activity so that the proposed needs are in accordance with the realities to be faced and can be immediately anticipated if there is a sudden change of activity;

c) Members of the Procurement Service Unit must maintain professionalism of their work. If the proposed needs to be tendered are directly related to the activity program of a member of the Procurement Service Unit, then the member cannot be directly involved in the process and must be replaced by another member to carry out the bidding;

d) Members of the Procurement Service Unit should also maintain their neutrality by not contacting, directly or indirectly, with providers of goods/ services other than in the process of anwijzing (explanation process) via the internet in the mechanism of e-procurement system; and

e) The commitments must be obeyed by each implementer of each task in order creating an environment that causing the principles of procurement which are Effective, Efficient, Accountable, Fair/ Not Discriminatory, Transparent, Open and Competing can still be maintained.

\section{Conclusion}

This study concludes that the main role of Procurement Service Unit still could be expanded. The role of Procurement Service Unit itself only limited on doing the auctioned procurement and choose the auction winner that suitable with the requirement conditions. From the fact that there is a role from procurement officer that can do e-purchasing and direct procurement with certain condition will be limiting the role of Procurement Service Unit. It also could create a crack even only a little - on the corrupt behavior. But the Government Procurement Policy Agency already tighten the rules on direct procurement by using e-purchasing system so it could be slowly reducing the corrupt behavior.

The second conclusion is about the intervention from the institution on Procurement Service Unit while doing the procurement process. To reduce the intervention from the institution, there are need some commitments from the actors in the procurement process to maintain the principles of procurement, which are Effective, Efficient, Accountable, Fair/ Not Discriminatory, Transparent, Open and Competing. Also, the introduction of e-procurement in Indonesia, that represent on the website that established by Government Procurement Policy Agency (https://lpse.lkpp.go.id/eproc) and other one that attached to Ministry of Health (www.lpse.depkes.go.id) will help the professionalism and neutrality of the members of the Procurement Service Unit.These conclusions still can be argued because it is still need some approval from the actors itself, including the Procurement Service Unit, User, and the provider. So, the future research is still can be conducted to strengthen it.

\section{References}

Azhari. (2011). Politik dan Birokrasi di Negra Bagian Sabah Malaysia (Studi Kasus Intervensi Pejabat Politik Terhadap Pejabat Birokrasi). Jurnal Hukum Dan Pembangunan, Vol. 41, No. 4, pp.594-622.

Brierly, J. L. (1963). The Law of Nations: An Introduction to the International Law of Peace. Gloucestershire: Clarendon Press.

Ferris, J. M., \& Graddy, E. A. (1998). A Contractual Framework for New Public Management Theory. International Public Management Journal, Vol. 1(2), pp.225-240.

Gordon Murray, J. (2009). Improving The Validity of Public Procurement Research. International Journal of Public Sector Management, Vol. 22(2), pp. 91-103.

Hanna, R., Bishop, S., Nadel, S., Scheffler, G., \& Durlacher, K. (2011). The Effectiveness of AntiCorruption Policy: What Has Worked, What Hasn't, and What We Don't Know-A Systematic Review, Technical Report. London: EPPI-Centre, Social Science Research Unit, Institute of Education, University of London.

Jensen, M. C., \& Meckling, W. H. (1976). Theory Of The Firm: Managerial Behavior, Agency Costs and Ownership Structure. Journal of Financial Economics, Vol. 3(4), 305-360.

Krippendorff, K. (2004). Content Analysis: An Introduction to Its Methodology (2nd ed., Vol. 79). California: Sage Publications, Inc.

Martini, R. (2010). Politisasi Birokrasi di Indonesia. POLITIKA, Jurnal Ilmu Politik (JIP), Vol. 1(1), pp.67-74.

Oppenheim, L. (1952). International Law: A Treatise. London: Longmans.

Panduranga, V. (2016). Transparency in Public Procurement Through E-procurement in India. Journal of Internet Banking and Commerce, Vol. 21(3), pp. 150-151.

Parry, C., \& Grant, J. P. (1986). Parry and Grant's Encyclopaedic Dictionary of International Law. New York: Oceana Publication. Inc.

Sadono, M., Wijaya, A. F., Wanto, A. H., \& Fujimoto, K. (2017). Efficiency of Public Procurement in Magelang City Government: A Comparative. Jurnal Ilmiah Administrasi Publik (JIAP), Vol. 3(3), 191-197.

Starke, J. G. (1978). An Introduction to International Law. London: Butterworths.

Walker, H., \& Harland, C. (2008). E-procurement in the United Nations: Influences, Issues and Impact. International Journal of Operations \& Production Management, Vol. 28(9), pp.831-857.

Widmalm, S. (2016). After NPM, curb your enthusiasm Over the Principal Agent Theory. Statsvetenskaplig Tidskrift, Vol.118(1), pp.127143. 
World Bank Group. (2016). Benchmarking Public Procurement 2016: Assessing Public Procurement Systems in 77 Economies. Washington, DC: World Bank. 